\title{
Applying Total Quality Model for Improving Quality In the Grassroots Jamu Enterprises
}

\author{
Kartika Nuringsih ${ }^{1}$ and Rodhiah ${ }^{2}$ \\ $\left\{\right.$ kartikan@fe.untar.ac.id $\left.{ }^{1}\right\}$ \\ ${ }^{1,2}$ Faculty of Economics, Tarumanagara University, Indonesia
}

\begin{abstract}
To develop the quality culture in the grassroots jamu enterprises practices, this article evaluates the model of quality management based on TQM. The business has existed for a long time, yet has remained unregistered. Therefore, their quality performances have not been entirely monitored by the government. It serves as an instrument to measure the implementation of quality culture in their daily work process, such as preparation input, productions, output, service quality, and environmental relationships. The goal of the social engineering is to develop awareness in the communities to control the quality continuously. The theoretical and policy implications will then be discussed.
\end{abstract}

Keywords: Grassroots Jamu Enterprises, Quality culture, TQM

\section{Introduction}

This article is inspired by the females small-scale commercial activities a kind of known as jamu gendong or herbs peddlers. Jamu is traditional herbal medicine, which used to maintain health and care disease (Elfami, 2006). These activities of peddlers are to provide self medication drinks for people living in urban areas and also to sell the herbal medicine which is produced by small-medium industry of traditional medicine. According to the Regulation of the Minister of Health of the Republic of Indonesia no. 006 year 2012, jamu peddler is defined as a business started by an individual using the ingredients of traditional medicine in the form of fresh liquid to be sold directly to customers (Depkes, 2012). The jamu sellers use the traditional knowledge to create herbal drinks, whereas these women have been doing the business for a long time in cities such as Greater Jakarta.

Consistent with prior studies by Torri, the community of sellers comes from a low socioeconomic stratum with a low level of education. Inspiried by (Hilmi, 2012), the creativity of making jamu was created by people living at the bottom of the pyramid. Therefore, the commercial activities of jamu peddlers are categorized as the grassroots enterprises. The innovation is necessary to increase the bargaining power of the communities similar to the implementation of technological innovation in India (Bulsara, Gandhi and Porey, 2013), the Indian people (Pansera and Sarkar, 2016), or using the gender empowerment and equality approach in rural India (Torri and Martinez, 2011).

The empowerment of the jати sector has become an important issue, due to its relation to the three aspects of development such as economy, social culture, and people's health. The Ministry of Health of The Republic of Indonesia created the program to encourage all elements in the society to preserve the culture of consuming jamu (Infarkes, 2015). In the practice, јати peddlers are not required to register their business. The work process is performed monotonously according to previous procedures. The impacts are the modern society has become less interested. This research is conducted as an appreciation for the women's independence as the pillar of their family's economy and the preserver of a cultural 
heritage. To enhance the sustainability of their business, the support for creative processes is required to produce jamu hygienically and safely.

Actually, there are still a lot of opportunities to develop jamu, under the condition that it is adjusted to the customer expectations. Normally, they prepare the good quality to capture for special moments. But, in the practice problems about quality are found. It is not easy for the jamu peddlers community to meet these standards. Therefore, they must change the conventional production processing into the quality culture. As an effort to close the disparity in the quality management, this research analyzes the quality management model by adopting the TQM.

In the previous study, (Cornelison, 2013) identified a number of benefits by implementing TQM. (Prajogo and Sohal, 2003; Almansour, 2012; Kibe and Wanjau, 2014) identified the involvement of TQM practices with the quality and performances. (Joiner, 2007) concluded that there is a strong positive relationship between the extent of implementation of TQM practices and organization performance. On the contrary, (Yusof and Aspinwall, 2000; Buranajarukorn, Gibson and Arndt, 2006) identified the failures of TQM. (Gallear, 1996) stated that small enterprises experience difficulties in implementing TQM. The other problems are the difficulties in determining the customer expectation and satisfaction (Harrington, Voehl and Wiggin, 2012). There is a high possibility that the community faces limitations in implementing the quality model.

The quality is inherent on many aspects, therefore the customer expectation of jamu peddlers has changed. Essentially, the jати makers have been aware of the hygiene and sanitations, but the continuity and commitment are still doubted by the society. To improve the performance, a quality is designed based on the profiles and business scales of the users. The focuses of this research are to design and to test the instrument of quality management model with the jamu peddlers as the respondents. Based on the practices, the reseach questions that will be explored in this study are the following: (1) How to identify the TQM practices in designing the quality management model for the jamu peddlers in Greater Jakarta? (2) How is the result of the instrument's reliability and validity test on the quality management model for jamu peddlers community?

The jamu system and the roles of jamu peddlers in the urban areas have been previously analyzed in the literature by (Torri, 2012, 2013; Maulana, Hanani and Hariyati, 2014) Based on practices, the purpose of this research is to develop a quality management model as a social engineering to create a supervising activity for the grassroots jamu enterprises. The implementation of the model is to maintain the quality of jamu sector in order to enhance the image and competitive advantage. The goal is to preserve the cultural heritage and to be a provider of self medication for people living in urban areas, such as Greater Jakarta.

The model is based on the principles of TQM with the implementation of quality culture on the daily work process, determining a supply chain that is suitable to achieve the quality target, and identifying customer expectation to create customer satisfaction and loyalty. According to (Alotaibi, 2014) quality culture is described as a critical success factor of the TQM implementation, because it reflects the environmental commitments towards the quality outcome, product, system, and process.

\section{Research Methods}

The framework of the grassroots jamu enterprises is related to managing the process, which involves taking inputs and performing value-added activities on these inputs to create output. Customer focus and service quality are important steps in serving the customers. The 
concept of service marketing by (Zeithaml, V A., Berry, L L., Parasuraman, 1988), identified dimensions of service quality, which are used as consideration in the service quality procedure. The objective of TQM is to achieve customer satisfaction, which is a key to predict customer desire to purchase a product in the future. It is related to the service quality as proven by (Mosahab, 2010; Mohammad and Alhamadani, 2011; Markovic, Loncaric and Loncaric, 2014).

The basic implications of TQM practices are based on the definition of TQM in Christofi et al. (2008) cited by (Chauhan, 2014) which set the requirement to gain the support of supply chain in creating product and service with high quality. (Gharakhani et al., 2013) defined as a systematic approach to increase productivity, quality, customer satisfaction, and profitability. (Sadikoglu and Olcay, 2014) explained that quality improvement is done on the product, service, and process with focusing on the customers' need and satisfaction. Based on the definitions, TQM is adopted for managing quality in the sector, which critical success factors are traced from (Ismail Salaheldin, 2009; Ali and Talib, 2013; Ghoshal, 2015). Therefore, the quality management model involves taking input until the environmental relationship to ensure the good quality for customer.

The collection of primary data is done through observation, interview, participation, and questionnaire. The results are the illustration of the neighborhood, kitchen, sanitation, raw material criterias, equipment storage, work process, usage of equipments, personal hygiene, clean water source, laboratory test, lifespan of business, expectation of communities, etc. Afterwards, an expert judgement is done with doctors and an apotechary of a pharmaceutical company. The group discussion involves three consumer groups, namely kindergarten teachers, local women association, and quality management class lecturers.

The secondary data uses the information, namely (1) (Infarkes, 2013, 2015) published by the Directory of Pharmaceutical and Health Equipment. (2) The Appendix of The Regulation of the Head of Indonesia National Agency of Drugs and Food Control or BPOM No.HK.00.05.4.1380 about the guidelines for making traditional (BPOM, 2005). (3) Regulation of the Minister of Health of the Republic of Indonesia No. 006 year 2012 on Industry and Traditional Medicine (Depkes, 2012). (4) Regulation of the Minister of Health No. 416/MEN.KES/PER/IX/1990 about the requirements and monitoring water quality (Kementerian Kesehatan, 1990). (5) The government policy to campaign the National Healthy with Jатu Movement. The information is used as a basis to create a quality management instrument which will be expounded in the form of questionnaire. To test the instrument, jamu sellers are asked to fill the questionnaire with consecutive choices from never (1) to always (5).

Population includes the jamu sellers in the Greater Jakarta, which uses the purposive sampling method to select the respondents. Criteria in choosing the samples are that the respondent has been running the business for at least 3 years and commits to maintain the quality of jamu. There were 70 respondents chosen from Serpong, Depok, Bogor, Jagakarsa, and Pasar Minggu. The data was collected from January to February 2016.

The reliability test analyzes how reliable the measurement is by using the Cronbach's Alpha. Validity test analyzes the measurement tool's ability in depicting the measured phenomenon. A corrected total-items correction method is used to analyze the items in the questionnaire in defining the variables. 


\section{Results And Discussion}

Respondents' descriptions are summarized (1) They have low formal education level, most only graduated from the elementary school (57.43\%), junior $(32.86 \%)$, senior high school (4.29\%), and 5.71\% never attended school. However, they are not illiterate. (2) The age range of the respondents are 41 to 50 years $41.43 \%$. The youngest seller is 23 years old, while the oldest is 64 years old. (3) $31.43 \%$ of the respondents have been working as jamu peddlers for 21 to 25 years, $21.29 \%$ for 16 to 20 years, and $15.71 \%$ more than 26 years. They started the business early, following their mothers, grandmothers, aunts, or sisters. (4) Half of the young respondents use bicycle $(31.43 \%)$, cart $(7.14 \%)$, motor cycle $(5.71 \%)$, and $55.71 \%$ go on foot while carrying a basket containing bottles of jamu. Thus, they are still considered relevant to be called jamu peddlers. Senior peddlers are able to carry 25 kilograms and serve 75 customers. They usually work twice a day and can serve up to 150 customers.

Based on the first question, the identification of the TQM practices on the quality model consists of several items. These are continuous improvement, supplier relationship, quality supplier, scientific approach, long term commitment, management customer relationship, information management, obsession with quality, leadership, empowerment and involvement, communication, and environment. The practices of TQM are improved in the process of input, production, output, service quality, and environmental relationship as element of the quality model for the jamu peddlers. Every stages in the model are deployed into procedure. Concerning the second question, Table 1 show the result in the process of input.

Table 1. Test Result in Input's Procedure.

\begin{tabular}{|c|c|c|c|}
\hline Items & Mean & $\begin{array}{c}\text { Std. } \\
\text { Deviation }\end{array}$ & Validity \\
\hline Sorting fresh & 4.36 & .539 & .471 \\
\hline ingredients & 4.60 & .493 & .755 \\
\hline Washing fresh & 4.29 & .783 & .843 \\
\hline ingredients & 4.36 & .817 & .824 \\
\hline Drying ingredients & & & \\
\hline Criterion of & 4.24 & .806 & .783 \\
\hline $\begin{array}{l}\text { storing ingredients } \\
\text { Identifying }\end{array}$ & 4.17 & .701 & .654 \\
\hline ingredients & 1.74 & 1.112 & .579 \\
\hline $\begin{array}{l}\text { Criterion of clean } \\
\text { water source }\end{array}$ & 4.70 & .462 & .323 \\
\hline Testing water & & & \\
\hline source & 3.14 & 1.535 & .786 \\
\hline in the laboratory & 4.26 & .716 & .865 \\
\hline $\begin{array}{l}\text { Avoiding the use } \\
\text { of chemical } \\
\text { substances }\end{array}$ & 4.34 & .720 & .786 \\
\hline Using glass bottles & 4.21 & .778 & .868 \\
\hline Criterion of & 4.43 & .579 & .691 \\
\hline equipment storage & 4.01 & .876 & .720 \\
\hline $\begin{array}{l}\text { Hygiene of } \\
\text { processing } \\
\text { location }\end{array}$ & 3.97 & .916 & .692 \\
\hline
\end{tabular}




\begin{tabular}{l} 
Selection of jamu \\
agets \\
Attention to expiry \\
dates \\
Criterion of \\
manufactured \\
jamu \\
Continuous \\
evaluation on \\
input process \\
$\quad$ Cronbach's Alpha 0,937, KMO's test .895 \\
$\quad$ Sig. Bartlett's test .000 Approx. Chi-square 894.917 \\
\hline
\end{tabular}

The Cronbach's Alpha Index is 0.937 and validity is 0.20 higher, so that it is deemed reliable and valid to measure the input process. KMO Index is 0.895 , meaning it is meritorius. The Bartlett's test is 5\% lower, which indicates the factor analysis is recommended and suitable. Two indicators result in high standard deviations, which indicate that there is a significant difference among the respondents in implementing the jamu processing procedure, specifically "Testing the water source in the laboratory" and "Using bottles made of glass to contain jamu". On the contrary, one indicator results in the lowest standard deviation, which indicates that most of respondents have the awareness not to use chemical substances.

The critical success factors of the first procedure consist of washing fresh ingredients (0.755), drying ingredients (0.843), criterion of storing ingredients (0.824), criterion of equipment storage (0.865), identifying ingredients $(0.783)$, using glass bottles $(0.786)$, selection of jamu agents (0.868), and criterion of manufactured jamu (0.720). In the practices, jamu peddlers seldom test the water source or the water well. Thus, they are not able to determine the quality of the water. Normally, jamu is supposed to be contained in glass bottles, but there are still a lot of peddlers that use plastic bottles, which are not recomended for liquid drink. The jamu sellers argued that using the glass bottles will make it heavier for them to carry, which are in contrast with the sellers who use bicycle, cart, or motor cycle. Related to the problems above, facilitators need to handle the technical water source testing process in laboratory and to encourage the use of glass bottles in the delivery of jamu products.

Table 2.Test Result in Production's Procedure.

\begin{tabular}{lccc}
\hline Items & Mean & $\begin{array}{c}\text { Std. } \\
\text { Deviation }\end{array}$ & Validity \\
\hline Washing hand with soap & 4.50 & .717 & .701 \\
Maintaining the body and mouth hygiene & 4.61 & .709 & .339 \\
Ingredient preparation location hygiene & & .587 & .420 \\
Wearing head cover, apron, and mask & 4.79 & .515 & .678 \\
Washing jamu ingredients & & & .709 \\
Measuring jamu ingredients & 2.71 & .806 & .668 \\
Washing the equipment & 4.61 & .490 & .606 \\
Washing and drying bottles & 4.50 & .367 & .589 \\
Sterilizing jamu bottles & 4.84 & .562 & \\
Boiling jamu ingredients & & & \\
Packaging of jamu in bottles Continuous evaluation & 4.69 & & \\
\end{tabular}




\begin{tabular}{|c|c|c|c|}
\hline on production process & $\begin{array}{l}1.81 \\
4.93 \\
4.27 \\
4.24\end{array}$ & $\begin{array}{c}1.407 \\
.259 \\
.741 \\
.711\end{array}$ & $\begin{array}{l}.523 \\
.259 \\
.580 \\
.524\end{array}$ \\
\hline
\end{tabular}

Cronbach's Alpha .831, KMO's test .830

Sig. Bartlett's test .000 Approx. Chi-square 380.152

Table 2 show that Cronbach's Alpha Index is 0.831 and the validity 0.20 higher so that the indicator is deemed reliable and valid to measure the production process. KMO Index is 0.830 which is deemed meritorius; while the Bartlett test is 5\% lower, which indicates that the factor analysis is recommended and suitable. The critical success factors of the second procedure consist of washing hand with soap (0.701), wearing head cover, apron, and mask (0.678), washing jamu ingredients (0.709), measuring jamu ingredients (0.668), and washing the equipment (0.606). Two indicators result in high standard deviation, indicating that there is relatively big differences in implementing the jamu processing procedure, specifically for "Wearing a head cover, apron, and mask" and "Sterilizing the glass bottles". On the contrary, one indicator results in the lowest standard deviation which indicates that most of the respondents have boiled the jamu ingredients perfectly or as required.

The analysis result for two procedures show relatively big differences for the usage of head cover, apron, mask, and the sterilization of glass bottles. Beside monitoring the overall jamu processing procedure, the roles of the facilitator are to remind the importance of personal hygiene and sterilizing the bottles correctly.

Table 3. Test Result in Output's Procedure.

\begin{tabular}{lccc}
\hline \multicolumn{1}{c}{ Items } & Mean & $\begin{array}{c}\text { Std. } \\
\text { Deviation }\end{array}$ & Validity \\
\hline Jamu is in a fresh condition & 4.95 & .204 & .481 \\
Size in serving jamu Hygiene of serving & & & .449 \\
equipment & 4.74 & .440 & .715 \\
$\quad \begin{array}{l}\text { Replacing water in bucket } \\
\text { Continuous evaluation on output process }\end{array}$ & 4.84 & .714 & .403 \\
\end{tabular}

Cronbach's Alpha .696, KMO's test .718

Sig. Bartlett's test .000 Approx. Chi-square 86.211

Table 3 show that Cronbach's Alpha Index is 0.696 and the validity is 0.20 higher so that the indicator is deemed reliable and valid to measure the output process. KMO Index is 0.718 which is deemed mediocre, while the Bartlett test result is $5 \%$ lower which indicates that the factor analysis is recommended and suitable. One indicator results in a high standard deviation which indicates that there are still differences in maintaining the hygiene of serving equipments. On the contrary, first indicator results in the lowest standard deviation which indicates that half of the respondents always serve jamu in fresh condition.

Based on the table above, the critical success factors consist of hygiene of serving equipment (0.715) and continuous evaluation on output process (0.709). Related to the analysis result, beside monitoring the overall jamu output procedure, the roles of the facilitator are to remind the jamu peddlers to maintain hygiene and display of the serving equipments. 
These equipments include basket, spoon, scarf, glass, napkin, and bucket. Other than that, they must always be constantly reminded to replace the water in the bucket routinely and wash the glasses after usage.

\begin{tabular}{lccc}
\multicolumn{4}{c}{ Table 4. Test Result in Service Quality's Procedure. } \\
\hline Items & Mean & $\begin{array}{c}\text { Std. } \\
\text { Deviation }\end{array}$ & Validity \\
\hline $\begin{array}{l}\text { Maintaining personal appearance } \\
\text { and behavior }\end{array}$ & 4.64 & .566 & .473 \\
$\begin{array}{l}\text { Maintaining personal hygiene } \\
\text { Sharing information with customers } \\
\text { Avoiding to talk much while serving }\end{array}$ & 4.74 & .440 & .520 \\
$\begin{array}{l}\text { jamu } \\
\text { Handling customer complaints }\end{array}$ & 4.74 & .472 & .470 \\
$\begin{array}{l}\text { Continuous evaluation on service } \\
\text { quality process }\end{array}$ & 4.51 & .737 & .348 \\
& 4.60 & .525 & .383 \\
\end{tabular}

Cronbach's Alpha .740, KMO's test .687

Sig. Bartlett's test .000 Approx. Chi-square 105.124

Tabel 4 show that Cronbach's Alpha Index is 0.740 and the validity is 0.20 higher so that the indicator is deemed reliable and valid to measure the service quality process. KMO Index is 0.687 which is deemed mediocre and the Bartlett test result is $5 \%$ lower which indicates that the factor analysis is recommended and suitable. The critical success factors of the procedure consist of four indicators, namely maintaining personal appearance and behavior $(0.473)$, maintaining personal hygiene $(0.520)$, sharing information with customers $(0.470)$, and continuous evaluation on service quality process $(0.532)$.

One indicator results in high standard deviation, which is to avoid talking much when serving jamu. A friendly and flexible personalities are related to the jamu peddlers. Thus, making a conversation with the customers reflects friendliness, empathy, compassion, and openness to the customers. Facilitators need to remind that habit to avoid the probability of infecting the customers with the contagious disease through saliva. On the contrary, third indicator results in the lowest standard deviation which indicates that half of the respondents pay attention to personal hygiene, such as the body, hand, leg, hair, mouth, and clothing.

Table 5. Test Result in Environmental Relationship's Procedure.

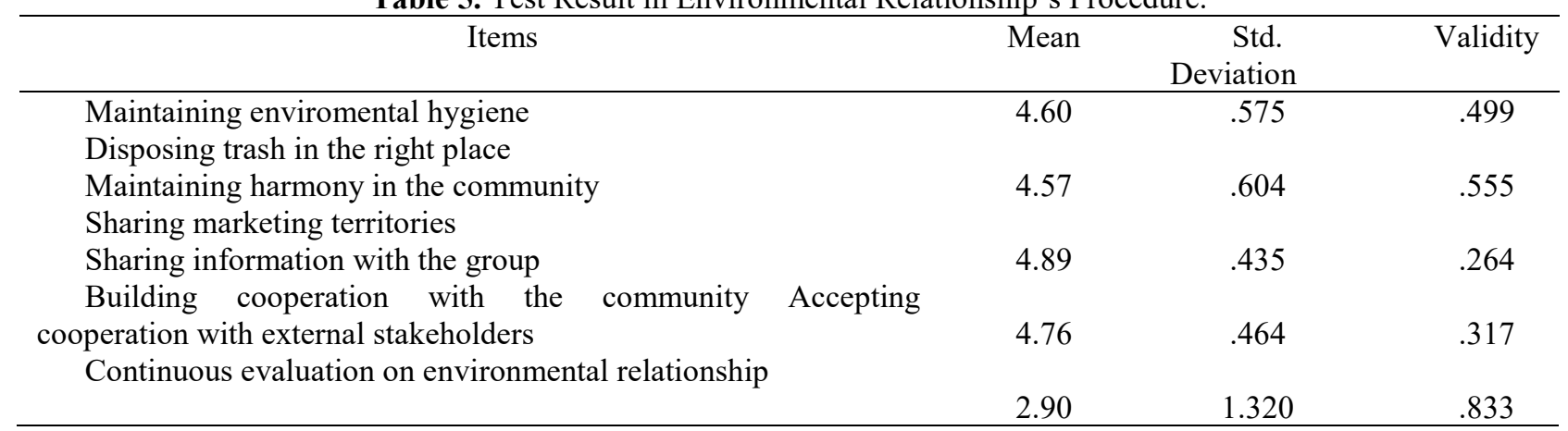


Cronbach's Alpha .829, KMO's test .639

Sig. Bartlett's test .000 Approx. Chi-square 483.018

Table 5 show that Cronbach's Alpha Index is 0.829 and the validity is 0.20 higher so that the indicator is deemed reliable and valid to measure the environmental relationship process. KMO Index is 0.639 which is deemed mediocre, while the Bartlett test result is $5 \%$ lower which indicates that the factor analysis is recommended suitable. The critical succes factor consist of three indicators, namely sharing information with group (0.833), building cooperation with community (0.889), and accepting cooperative offers from external stakeholders (0.723). Indicators result in high standard deviation. On the contrary, third indicator results in the lowest standard deviation which indicates that most of the respondent respect the concordance in the jати community. Facilitators need to remind them to share the information related to jamu, facilitating to create the association of jamu peddlers, and mediating external cooperation to improve the performance of grassroot jamu enterprises in Greater Jakarta.

As many as 32 items are classified as valid indicators of the quality management model of jamu peddlers. To meet the customer expectation and quality standards, nine items with the highest standard deviations need to be focused by supervisors. Five items indicate that the procedure implementation has been done correctly by the participants. Therefore, the community is requested to maintain it continuously and to educate their colleagues to implement the procedure. The facilitators need to monitor and evaluate the practices continuously. Morever, this procedure can control the risk and provide the daily self medication for customers.

Basicly, the jати makers care about hygiene and sanitations, but, the way of materials preparation is often different. The usage of equipments such as the boiling pot, glass bottling and several devices to serve customers are also different from seller to seller. In order to reduce the quality standard disparity among the jamu makers, a quality control circle can be deployed to monitor their activities. The role of facilitators, volunteers, department of health, traditional medicine industry, educational institutions, and public figures are able to share information through the control circle.

The model is inspired by prior researchers which adopt TQM practices to manage quality. The development of quality model has been simplified so that it is easy to apply on the daily work process. Inspired by (Mustaffa and Asyiek, 2015) to ensure continuity of the applying, it is important to involve a supervisor. The relation between TQM based quality management and jamu gendong practices serves as a foundation in building a pillar to empower the jати sector. The implementation of this model will improve the customer image toward the performance of jати sellers, therefore will be able to increase the bargaining power of jати peddlers, preserve the local genius products, and provide the daily self medication for people living in urban and periurban areas in Greater Jakarta or other cities. 


\section{Conclusions}

The development of jamu sector in Indonesia is related to the tradition, natural resource, and home industry. Therefore, it is very unlikely for the idea to be disapproved in general. If there were any disapproval, the main cause would be the customers' lack of trust for the work activities of the jamu sellers. Quality management model adopts TQM in the quality management system for the grassroots jamu enterprises. To meet the expectation of the actual customers, the efforts to maintain quality, hygiene, and safety are deemed good enough. The aspect is very important to be introduced to the jamu peddlers community to gain knowledge about how to capture the customers perception of risk and benefit after consuming the traditional herbs. These are important to be acknowledged by the sellers to gain profits from the business without ignoring the customer risks.

However, in order to maintain the sustainability of the local jamu business, it is necessary to improve the knowledge about the managing of input, production, output, service quality, and environmental relationship further. One of obstacles is sustainability of commitment. But, as long as the stakeholders commit to preserve the cultural heritage, a quality improvement process will be realized continuously.

\section{Acknowledgements}

Thank to the Ministry of Research, Technology, and Higher Education of the Republic of Indonesia which funded the research. Lastly, we would like to thank the jamu gendong community for their willingness to share the information related to jamu business

\section{References}

[1] Ali, K. A. M. and Talib, H. H. A. (2013) 'Total Quality Management Approach for Malaysian Food Industry: Conceptual Framework', Journal of Advanced Management Science, 1(4), pp. 405-409. doi: 10.12720/joams.1.4.405-409.

[2] Almansour, Y. M. (2012) 'The Impact of Total Quality Management Components on Small and Medium Enterprises ' Financial Performance in Jordan', ResearchersWorld, III(1), pp. 87-91.

[3] Alotaibi, F. M. S. (2014) 'Impact on quality culture of total quality management practices', International Journal of Business and Economic Development, 2(3), pp. 3548.

[4] BPOM (2005) 'Pedoman cara pembuatan obat tradisional yang baik', Pedoman Cara Pembuatan Obat Tradisional yang Baik, pp. 1-28. doi: 10.1017/CBO9781107415324.004.

[5] Bulsara, H. P., Gandhi, S. and Porey, P. D. (2013) 'Grassroots Innovations to TechnoEntrepreneurship through GIAN - Technology Business Incubator in India: A Case Study of Nature Technocrats', International Journal of Innovation, 1(1), pp. 49-70. doi: 10.5585/iji.v1i1.1.

[6] Buranajarukorn, P., Gibson, P. R. and Arndt, G. (2006) 'The problems of implementation of Total Quality Management in Thai manufacturing SMEs', Asia Pacific Industrial Engineering and Management Systems and Chinese Institut of Industrial Engineers Conference, pp. 234-248.

[7] Chauhan, Y. A. (2014) 'BENEFITS DERIVED BY SMEs THROUGH IMPLEMENTATION OF TQM', International Journal of Research in Engineering and Technology, 03(05), pp. 470-474. 
[8] Cornelison, P. (2013) 'The effectiveness of total quality management principles in the printing industry’, pp. 1689-1699. doi: 10.1017/CBO9781107415324.004.

[9] Depkes (2012) 'Peraturan Menteri Kesehatan Republik Indonesia nomor 006 tahun 2012 tentang industri dan usaha obat tradisional', peraturan menteri kesehatan RI.

[10] Elfami (2006) Phytochemical and Biosynthetic Studies of Lignans, with a Focus on Indonesian Medicinal Plants.

[11] Gallear, D. N. (1996) 'Total Quality Management in SMEs', 24(1), pp. 83-106.

[12] Gharakhani, D. et al. (2013) 'Total Quality Management and Organizational Performance', American Journal of Industrial Engineering, 1(3), pp. 46-50. doi: 10.12691/ajie-1-3-2.

[13] Ghoshal, M. (2015) 'Descriptive analysis of present quality management practices of Indian micro, small and medium enterprises', Int. J. Indian Culture and Business Management, 10(1), pp. 16-41.

[14] Harrington, H. J., Voehl, F. and Wiggin, H. (2012) 'Applying TQM to the construction industry', The TQM Journal, 24(4), pp. 352-362. doi: 10.1108/17542731211247373.

[15] Hilmi, M. F. (2012) 'Grassroots Innovation from the Bottom of the Pyramid', Current Opinion in Creativity, Innovation and Entrepreneurship, 1(2), pp. 1-3.

[16] Infarkes, B. (2013) 'Pendampingan bagi Pelaku Usaha Jamu Racikan dan Jamu Gendong', Oktober.

[17] Infarkes, B. (2015) 'Bugar dengan Jamu', Januari-Februari.

[18] Ismail Salaheldin, S. (2009) 'Critical success factors for TQM implementation and their impact on performance of SMEs', International Journal of Productivity and Performance Management, 58(3), pp. 215-237. doi: 10.1108/17410400910938832.

[19] Joiner, T. A. (2007) 'Total quality management and performance', International Journal of Quality \& Reliability Management, 24(6), pp. 617-627. doi: $10.1108 / 02656710710757808$.

[20] Kementerian Kesehatan (1990) 'Peraturan Menteri Kesehatan RI 416/MENKES/PER/IX/1990 terntang syarat-syarat dan Pengawasan Kualitas Air', pp. $1-10$.

[21] Kibe, E. and Wanjau, K. (2014) 'The Effect of Quality Management Systems on the Performance of Food Processing Firms in Kenya .', IOSR Journal of Business and Management (IOSR-JBM), 16(5), pp. 61-72.

[22] Markovic, S., Loncaric, D. and Loncaric, D. (2014) 'Service quality and customer satisfaction in the health care industry - Towards health tourism market', Tourism and Hospitality Management, 20(2), pp. 155-170.

[23] Maulana, A., Hanani, E. and Hariyati, R. T. S. (2014) 'CORRELATION OF THE KNOWLEDGE OF JAMU GENDONG SELLER ABOUT INGREDIENT AND BENEFIT AGAINST THE KNOWLEDGE AND CUSTOMER' S PERCEPTION Adhen Maulana Endang Hanani Rr Tutik Sri Hariyati', in International Proceedings of Social and Behavioral Science, pp. 74-81.

[24] Mohammad, A. A. S. and Alhamadani, S. Y. M. (2011) 'Service Quality Perspectives and Customer Satisfaction in Commercial Banks Working in Jordan', MIddle Eastern Finance and Economics, 14(4), pp. 60-72.

[25] Mosahab, R. (2010) 'Service Quality , Customer Satisfaction and Loyalty: A Test of Mediation', International Business Research, 3(4), pp. 72-80. doi: 10.5539/ibr.v5n1p3.

[26] Mustaffa, C. S. and Asyiek, F. (2015) 'Conceptualizing framework for women empowerment in indonesia: Integrating the role of media,interpersonal 
communication,cosmopolite,extension agent and culture as predictors variables', Asian Social Science, 11(16), pp. 225-239. doi: 10.5539/ass.v11n16p225.

[27] Pansera, M. and Sarkar, S. (2016) 'Crafting sustainable development solutions: Frugal innovations of grassroots entrepreneurs', Sustainability (Switzerland), 8(1), pp. 1-51. doi: 10.3390/su8010051.

[28] Prajogo, D. I. and Sohal, A. S. (2003) 'The relationship between TQM practices, quality performance, and innovation performance', International Journal of Quality \& Reliability Management, 20(8), pp. 901-918. doi: 10.1108/02656710310493625.

[29] Sadikoglu, E. and Olcay, H. (2014) 'The Effects of Total Quality Management Practices on Performance and the Reasons of and the Barriers to TQM Practices in Turkey _ Table 1', Advances in Decision Sciences, 2014, pp. 1-17. doi: $10.1155 / 2014 / 537605$.

[30] Torri, M.-C. (2012) 'The jamu system: linking small-scale enterprises, traditional knowledge and social empowerment?', International Journal of Entrepreneurship and Small Business, 15(4), p. 488. doi: 10.1504/IJESB.2012.046477.

[31] Torri, M.-C. (2013) 'Knowledge and Risk Perceptions of Traditional Jamu Medicine among Urban Consumers', European Journal of Medicinal Plants, 3(31), pp. 25-39. doi: 10.9734/EJMP/2013/1813.

[32] Torri, M.-C. and Martinez, A. (2011) 'Gender Empowerment and Equality in Rural India: Are Women's Community-Based Enterprises the Way Forward?', Journal of International Women's Studies, 12(1), pp. 157-176.

[33] Yusof, S. M. and Aspinwall, E. (2000) 'TQM implementation issues: review and case study', International Journal of Operations and Production Management, 20(6), pp. 634-655. doi: 10.1108/01443570010321595.

[34] Zeithaml, V A., Berry, L L., Parasuraman, A. (1988) 'SERVQUAL: A multiple-item scale for measuring consumer perceptions of service quality.', Journal of Retailing, 64(1), pp. 12-40. 